\title{
Chapter 7 \\ The Impact of Higher Education Expansion Policy on the Wages of Female and Male College Graduates
}

\begin{abstract}
Based on the quasi-natural experiment methods (DID method and DDD method), using six waves longitudinal survey data of the China Health and Nutrition Survey, this study investigates the influence of the Higher Education Expansion Policy (HEEP) on the wage levels of young college graduates and compare the different policy influences by gender. The results indicate that the HEEP does not affect the wage levels of young college graduates significantly; the HEEP decreased the wage level of new college graduates in the short term, whereas the negative effect disappears in the long term for both female and male younger workers; the gender differences in the impacts of the policy on the wage levels of new college graduates are smaller.
\end{abstract}

Keywords Higher education expansion policy • College graduates • Gender • Wage $\cdot$ China

\subsection{Introduction}

China's planned economic system was reformed after 1978. A set of new policies were implemented by the Chinese government, and China experienced great economic growth which achieved an average GDP growth rate of around 10\% during the 1990s and 2000s. In 1999, the Higher Education Expansion Policy (HEEP) was implemented by the government. Along with the policy implementation, the number of college graduates increased from 1.08 million in 1998 to 6.381 million in 2013 (NBS 2016). ${ }^{1}$ According to the general market equilibrium mechanism, when labor demand is consistent, an increase of the college graduate labor supply in the short term may decrease the graduate wage level (negative effect); whereas the increase of college graduate workers may promote technological innovation and increase economic growth. When the labor demand for college graduates increases greatly with economic growth or technological progress, the college graduate wage level

This chapter is a revised and developed version of Ma, X. (2019). The impact of higher education expansion policy on the wage of college graduates in China. International Journal of Economics and Finance, 11(5), 68-84. Copyright (C) reprinted by permission of the Journal of International Journal of Economics and Finance. 
may increase even after the implementation of the HEEP (positive effect). Thus, the influence of the policy is not clear and it deserves empirical investigation.

This study employs a quasi-experiment method based on the DID method (Difference in difference method) and DDD method (triple differences method) to estimate the impact of the HEEP on college graduates' wages in China, and compare of the differences of impacts by female and male groups. It uses data from a longitudinal survey data from the Chinese Health and Nutrition Survey (CHNS) conducted from 1997 to 2011. These analyses build on the findings of relevant published research.

This chapter is structured as follows: Sect. 7.2 introduces the implementation of higher education expansion policy, Sect. 7.3 introduces the channels by which the HEEP y can affect college graduates wage, and introduces previous empirical studies on the issue. Section 7.4 gives the framework of the empirical analysis, including models and datasets. Section 7.5 presents estimated results and explains these results. Section 7.6 summarizes the conclusions.

\subsection{Hight Education Expansion Policy in China During the Economic Transition Period}

The Chinese government promoted the enrollment of compulsory education and higher education since the planned economy period of the 1950s. This study focuses on the HEEP during the market-oriented economy period (transition period) as follows.

In 1999, the State Council approved the Plan of Revitalizing Education in the Twenty-First Century proposed by the Ministry of Education to expand higher education enrollment. The plan included various strategies to encourage universities to set up multiple campuses as well as instituting the private colleges. The plan called for an increase in public education expenditures, especially in tertiary education. The proposal aimed at an increase in the gross enrolment ratio in tertiary education, a rise in the student-teacher ratio, and an increase in state educational funding. A target was set in the plan for China to reach a tertiary enrollment ratio of $15 \%$ by 2010 , defined as "mass higher education" (Trow 1972, 1973). In addition, in 2004, the Chinese State Council passed A Plan of Education Revitalization 2003-2007. This plan focused on the improvement of teaching, mainly for universities on the " 985 " and " 211 " lists. It emphasized the reform of the teaching and evaluation system, and the implementation of the Improvement of New Graduates Employment Program policy. It required the higher education system to prepare new graduates for the jobs market. In 2010, the National Outline for Medium and Long-term Reform and Development (2010-2020) was published. This plan sought to improve teaching, scientific research, and the social relevance of education, and to let the total number of enrolled college student increase to 33 million by 2020: this indicates that higher education expansion will continue. 
China's higher education developed rapidly with the implementation of these polices (see Fig. 7.1). From 2000 to 2011 the enrollment of regular college ${ }^{2}$ students expanded from 5.56 to 26.25 million, and annual college graduate students increased from 0.95 to 6.81 million. From 2000 to 2015 enrollment of senior high school students expanded from 12.01 to 23.74 million, and annual college graduate students increased from 30.15 to 79.77 million. It is observed that with the implementation of the HEEP, both the students and graduates of college and senior high school increase

\section{Panel A: Number of Students}

Unit: 10 thousands

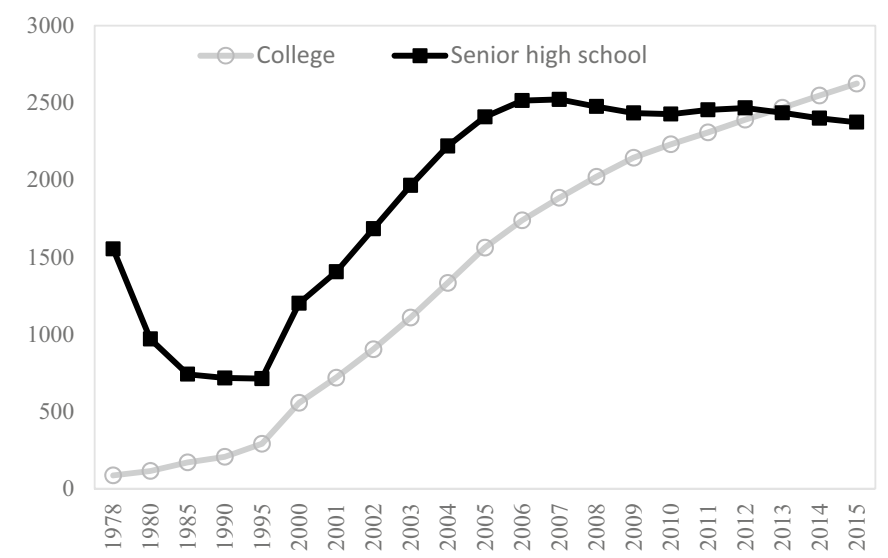

Panel B: Number of Graduates

Unit: 10 thousands

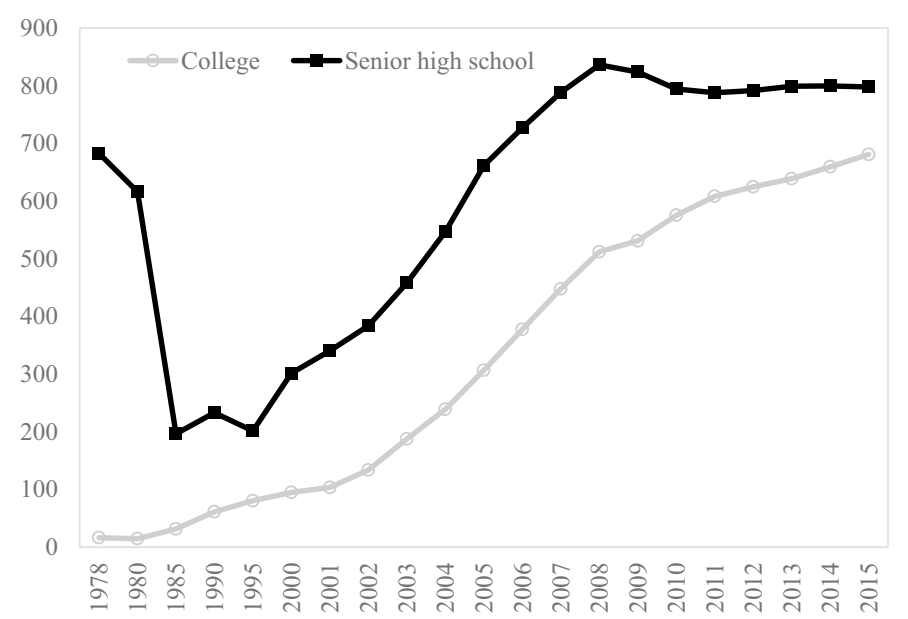

Fig. 7.1 Numbers of students in schools and graduates from 1990 to 2015. Source Based on data from China Statistics Yearbook 2016 
greatly. It is thought that the increase in the higher education labor supply affects the employment of young graduates.

\subsection{Literature Review}

\subsubsection{The Channels of the Impact of Higher Education Expansion Policy on the Wages of College Graduates}

How does the HEEP affect the wage level of new college graduates? Based on economic theories, both positive and negative effects can be considered as follows.

First, based on the general market equilibrium mechanism, when the labor demand is constant, the increase of new college graduates supply in the short term may decrease the college graduate wage level (negative effect). Whereas, when economic growth is strong or technological innovation is progressing, the increase of demand for higher education and highly-skilled workers is greater than the supply, the wage level for college graduates may not change or may even increase during policy implementation (positive effect).

Second, according to human capital theory (Becker 1964; Mincer 1974), when the increase in productivity of a higher education worker is greater than that for workers with a low- and middle-education levels, the wage level which is set by the firm may be more for the worker with a higher education than for low- and middle- education worker (positive effect).

Third, according to signal theory (Spence 1976), the education level can be used as a sign by which the firm can identify the ability of an employee. In the absence of a better way for the firm to identify an employee's actual ability, the firm may evaluate and judge the worker' ability based on the employee's educational attainment. When the firm believes the college graduates are the most productive employees than the counterparts, the wage level may be higher for college graduates (positive effect). However, when the number of college graduates increases, the signal function may lead the firm to recruit college graduates to substitute the high school graduates and recruit graduates with second or postgraduate degrees to fill jobs formerly given to college graduates: this may cause the wage of the college graduates decreased (negative effect).

Based on these theories and hypotheses the influence of the higher education expansion policy on the wage of college graduates is not clear. Therefore, an empirical study is needed. 


\subsubsection{Previous Empirical Studies on the Issue}

For the empirical study results on the impact of the HEEP on the labor market, we summarize its impact on wage as follows. ${ }^{3}$

$\mathrm{He}$ (2009) used Chinese Health and Nutrition Survey (CHNS) data to estimate the education return from 1991 to 2006 based on the OLS, and shows that the education effects on wage (education return) decreased from 2004 to 2006 . He points out that the higher education expansion policy may affect the wage level of higher education graduates. Chang and Xiang (2013) analyzed the change of education return from 1989 to 2009 using CHNS data. Based on a Heckman two step model, they estimate the education return for the pre-policy period (1989-1993, 1997, 2000) and postpolicy period $(2004,2006,2009)$ groups, and the group aged 19-26 and the group aged 27-55. They found that compared to the pre-policy period, the wage gap between college and senior high school graduates increased during the post-policy period. It seems that the policy positively affects the wage level of college graduates. Using data from the China Urban Labor Survey (UCLS) in 2001, 2005, and 2010, Gao and Smyth (2015) estimated the education return based on OLS and instrument variables methods, they indicate that the education return increased from 2001 to 2005 and 2010. Xia et al. (2016) employed CHNS data from 2000 to 2009 to estimate education return based on the quantile regression model and Firpo, Fortin, and Lemieux (FFL) decomposition method. They find the education return increased from 2000 to 2009 and the education return is higher for the high-wage group than the middle and low wage groups. It should be noticed that these previous empirical studies did not consider the unobserved heterogeneity problem among various groups. Wu and Zhao (2010) addressed this and estimate the impact of the HEEP on wage directly based on a DID method and DDD method using data from the China Urban Labor Survey (CULS) for 2002 and Chinese 1\% Population Census data. It is found that the policy decreases the wage level based on the DID method whereas the impact of the policy on wages are not statistically significant based on DDD method Yao et al. (2014) also estimated the policy influence based on DID and DDD methods using China Urban Household Income Survey data from 1998 to 2005. They find that the higher education expansion policy negatively affects the wage of young college graduates, but the negative effect decreases in the long term. Wu and Zhao (2010), and Yao et al. (2014) used the same DID and DDD methods to find a different outcome for the impact of policy on wage. This suggests that more research is needed on this topic.

\subsubsection{Contributions of This Study}

Although the previous empirical studies investigate the impact of higher education expansion on the wages of college graduates, the empirical studies based on an experiment analysis method are scarce. There remain further areas to be researched. The main contributions of this current study can be summarized as follows. 
First, the impact of policy may vary according to period. For example, in a perfect competition market, in a short-term, the dramatic increase of college graduate labor supply may affect wage level of new college graduates. Whereas in a long-term, the influence of the policy may decrease because the labor demand for college graduates may increase with economic growth or industrial structure upgrading. Yet there is no empirical study based on DID and DDD methods which scrutinizes the short term and long-term effects. This study tries to address this need.

Second, because there remains the gender wage gap in China (Gustafsson and $\mathrm{Li}$ 2000; Li and Ma 2006, 2015; Ma et al. 2013; Ma 2018a, b), to consider the gender disparities of the family responsibility, labor participation behavior and work efforts, this study also compares the policy influence by gender.

Third, as the one of features of Chinese economy, the Chinese labor market is segmented by various sectors and regions. For example, due to the large regional disparity in China, the impact of the policy may differ by regions. This study also analyzes the effect of the policy in the Eastern, Central, and Western Regions. In additions, there remains the discrimination against migrants by the Hukou system (Meng and Zhang 2001; Song and Appleton 2006; Ma 2018c), we also investigate the policy effects by the rural Hukou and urban Hukou resident groups.

Fourth, a set of robustness checks is employed to test the analysis appropriateness. These results may develop previous studies on the issue.

\subsection{Methodology and Data}

\subsubsection{Model}

The DID method is used to investigate the impact of higher education expansion policy on wages:

$$
Y_{i t}=a+\beta_{1} \text { Year }_{t}+\beta_{2} \text { Treat }_{i t}+\beta_{3} \text { Treat }_{i t} * \text { Year }_{t}+\beta_{4} X_{i t}+\varepsilon_{i t}
$$

The object analyzed by the DID method is the college graduates aged 21-40. In Eq. (7.1), $Y$ is hourly wage logarithms, $i$ stands the individual, $t$ is years, Year is post-policy period $(2004,2006,2009$, and 2011 in this study), Treat is the treatment group, $X$ includes the individual characteristics variables (e.g. family numbers, health status, and gender), Hukou, and the regional characteristics variables. $a$ is the constant term, and $\varepsilon$ is the error term. $\beta_{1}-\beta_{4}$ represent the estimated coefficient for each variable. This study uses the survey years before the implementation of the higher education expansion policy (1997, and 2000) as the pre-policy period and the years of 2004, 2006, 2009, and 2011 as the post-policy period. In this study the treatment group is defined as college graduates aged $21-25$ and the control group is defined as college graduates aged $31-40$. 
The DDD method is shown by Eq. (7.2). The object analyzed by the DDD method includes both college and senior high school graduates aged 21-40.

$$
Y_{i t}=a+\beta_{1} \text { Year }_{t}+\beta_{2} \text { age }_{21-25 i t}+\beta_{3} \text { Colle }_{i t}+\beta_{4} \text { age }_{i 21-25 t} * \text { Colle }_{i t} * \text { Year }_{t}+\beta_{5} X_{i t}^{\prime}+\beta_{\lambda} \lambda_{i t}+\varepsilon_{i t}
$$

In Eq. (7.2), age a $_{21-25}$ is the group aged 21-25, Colle is the college graduate group, $X^{\prime}$ includes the individual characteristics variables, the regional characteristics variables and other variables including the interaction item of age and year dummy variable, the interaction item of college graduate and year dummy variable, and the interaction item of college graduate and age dummy variable.

In the Eqs. (7.1) and (7.2), $\beta_{3}$ and $\beta_{4}$ represents the estimated coefficient of DID or DDD items. When $\beta_{3}$ and $\beta_{4}$ is a negative value, and it is statistically significant, it indicates that the implementation of the higher education expansion policy reduces the wage level of young college graduate, and vice versa.

A sample selection bias problem may exist therefore a DID method or DDD method based on the Heckman two-step model is also used to correct the bias (Heckman 1979). In Eqs. (7.1) and (7.2), the inverse Mills' ratio $\lambda$ is an adjusted item. $\lambda$ is calculated by $\lambda=\phi\left(\gamma_{t} Z_{i t}\right) / \Phi\left(\gamma_{t} Z_{i t}\right), \phi(\cdot), \Phi(\cdot)$ is a normal density function and distribution function based on the probit regression model, $Z$ is factors which affect the employment status selection (e.g. to work or not to work), $\gamma$ represents the coefficients of these factors.

\subsubsection{Data}

This study employs six waves (1997, 2000, 2004, 2006, 2009, and 2011) longitudinal data from the Chinese Health and Nutrition Survey (CHNS) conducted from 1997 to 2011. CHNS is a nationwide longitudinal survey conducted by the Carolina Population Center at the University of North Carolina and the National Institute for Nutrition and Health (NINH, former National Institute of Nutrition and Food Safety) at the Chinese Center for Disease Control and Prevention. The survey took place over seven days using a multistage, random cluster process to draw a sample of about 7,200 households with over 30,000 individuals in fifteen provinces and municipal cities that vary substantially in geography, economic development, public resources, and health indicators. Although the longitudinal survey began in 1989 this study uses the survey data from 1997 to 2011 because the higher education expansion policy was implemented in 1999. This study uses samples from 11 provinces and municipalities: Beijing, Liaoning, Heilongjiang, Shanghai, Jiangsu, Shandong, Hernan, Hubei, Hunan, Guangxi, and Guizhou.

The independent variable is the logarithms value of hourly wage. The wage is the earning income including the basic wage and the allowance, and not including the bonuses. The nominal wage is adjusted to the real wage by the $2011 \mathrm{CPI}$ (Consumption Price Index). 
Figure 7.2 shows both the monthly wage and hourly wage from 1989 to 2011. Because the higher education expansion policy was implemented in 1999, the effect of the policy on wage appears in the period after 2002 for college graduates whose degree takes for three years and 2003 for college graduates whose degree takes for more than four years. Thus the period from 1989 to 2000 is the pre-policy period and the survey period from 2004 to 2011 is the post-policy period. The monthly wage and hourly wage are calculated for three groups: college graduates aged 21-25; college graduates aged 31-40, and senior high school graduates aged 21-25. The change

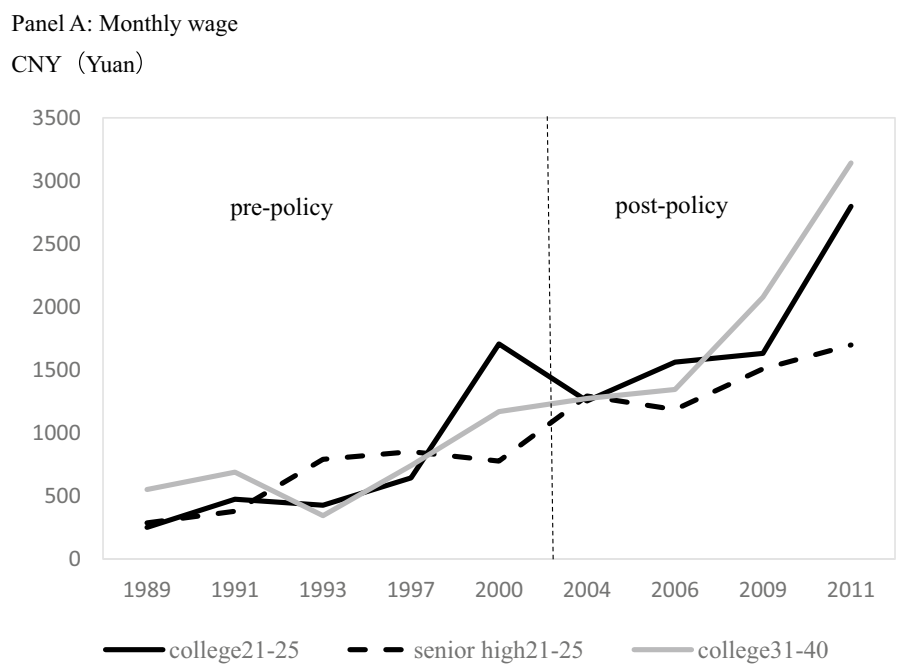

Panel B: Hourly wage

CNY (Yuan)

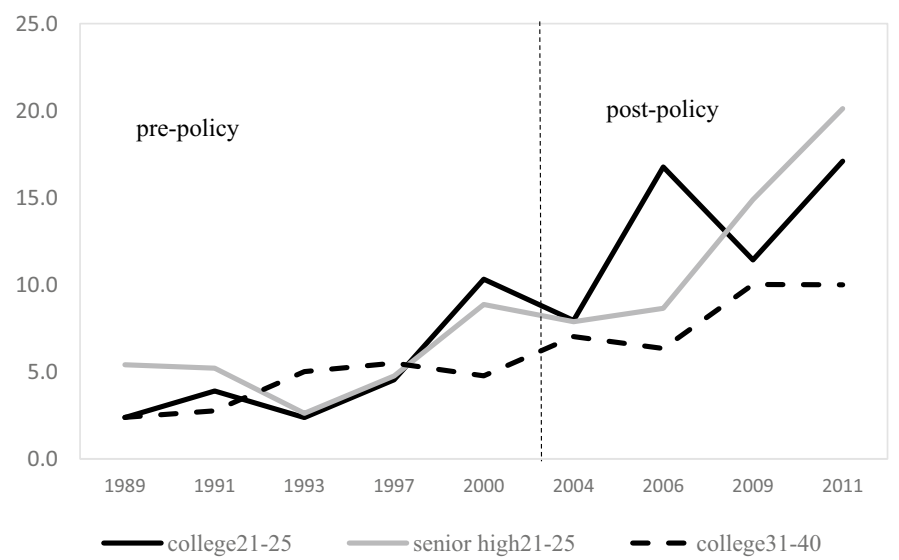

Fig. 7.2 Wage by age and education groups from 1989 to 2011. Source Calculated based on CHNS 1989-2011 
tendency of wages from 1989 to 2011 is similar for Panel A (monthly wage) and Panel B (hourly wage). It is observed that as the wage increased from 1989 to 2011, the wage gaps between the three groups are different. It indicates that the work hours may be different between the three groups. To consider the influence of work hours, the hourly wages are used in the study. The main results of Panel B (hourly wage) in Fig. 7.2 are as follows.

First, when compare the college graduates aged 21-25 with the college graduates aged 31-40, it is observed that except in 1993 and 1997, the wage is higher for the college graduates aged 21-25 than for the college graduates aged 31-40 during both pre-policy period and post-policy period. However, for college graduates aged 21-25, the wage decrease is greater for 2004 and 2009. It is indicated that the higher education expansion policy seems likely to reduce the wage gaps in both 2004 and 2009. Excepting the period of world financial crisis in 2007, the higher education expansion policy seems to affect the wage of young college graduates in a short term.

Second, to compare the college graduates aged 21-25 with the senior high school graduates aged 21-25, even though the wage gaps between these two groups are different by periods, the relations between these two groups are not observed clearly. For example, during the pre-policy period, the wage is higher for senior high school graduates aged from 21 to 25 than the counterpart, whereas the wage is higher for college graduates aged 21-25. Moreover, during the post-policy period, the wage is higher for college graduates aged 21-25 in 2006 and it is lower in 2009 and 2011 than for the counterpart.

\subsubsection{Variable Setting}

The main dependent variables are constructed as follows (see Appendix Table 7.11). First, Year is a set of year dummy variables. In the study, 1997, 2000 is the prepolicy period, and 2004, 2006, 2009, and 2011 is the post-policy period. DID in the Eq. (7.1) is the interaction term of the two variables used: the post-policy period and treatment group dummy variables. The treatment group is defined as the college graduates aged 21-25. DDD in Eq. (7.2) is the interaction term of the three variables used: the post-policy period dummy, the group aged 21-25 years old dummy, and the college graduate dummy variables (Year * Age $21-25 *$ Colle).

Second, for the other factors, (1) the years of experience and health status are used as human capital. (2) The male dummy is used to control the gender gap in labor market. (3) To control the influence of occupation on wage, the occupation dummy variables (manager, technician, clerk, agriculture job, high-level manufacturing job, low-level manufacturing job, service job, the other job) are constructed. (4) To consider the labor market segmentation by various groups and regions, the private sector dummy, the urban areas, and region blocks (Eastern, Central, Western) dummy variables are constructed.

Third, the first-step in the Heckman two-step model is a work probability function (e.g. work or not to work). The factors that affect labor participation behavior are also constructed. They are the individual variables including age, number of 
family members, gender, health status, urban hukou, and the province level variables including regional ratio of fixed asset investment to GDP, ratio of tertiary industry to GDP, ratio of trade to GDP, and GDP per capita. ${ }^{4}$

It is thought that the results may be sensitive by the treatment group setting. In this study, the rule to distinguish the treatment group and control group is based on age categories. To compare the impact of the higher education expansion policy on wage by various age category groups, an analysis by the following function is used:

$$
\begin{gathered}
Y_{i t}=a+\beta_{1} \text { year }_{i}+\beta_{2} \text { age }_{i t}+\beta_{3 a} \sum_{a=21}^{30} \text { age }_{i t} * \text { year }_{t}+\beta_{4} X_{i t}+\varepsilon_{i t} \\
Y_{i t}=a+\beta_{1} \text { year }_{i}+\beta_{2} \text { age }_{i t}+\beta_{3} \text { Colle }_{i t}+\beta_{3 a} \sum_{a=21}^{30} \text { age }_{i t} * \text { year }_{t} * \text { Colle }_{i t}+\beta_{4} X_{i t}+\varepsilon_{i t}
\end{gathered}
$$

In Eqs. (7.3.1) and (7.3.2), $i$ stands for the individual, $t$ for years, year for policy implementation years (2004, 2006, 2009, and 2011 in this study), age for the age dummy, $X$ for the individual characteristics variables (e.g. family numbers, health status, gender), the regional characteristics variables and other variables. In the Eq. (7.3.2), $X$ also includes the interaction item of age and year dummy variable, the interaction item of college graduate and year dummy variable, and the interaction item of college graduate and age dummy variable. $a$ is the constant term, and $\varepsilon$ is the error term. $\beta$ represents the estimated coefficient for each variable. The results of $\beta_{3 a}$ are summarized in Table 7.1.

The results indicate that although all coefficients are not statistically significant, the higher education expansion policy negatively influences the wage of college graduates aged 21-25; whereas it almost positively affects the wage of the university graduates aged 26-30. It is observed that the influences of the policy are different between the group aged 21-25 and the group aged 26-30. The results of estimation 2 showed a similar tendency, the influence of the policy is negative for the treatment group (group aged 21-25), whereas they are almost positive for the other group. It is confirmed that to define the treatment group as college graduates aged 21-25 is appropriate. However, the impacts of the policy on the college graduate group aged 26-30 are various, it indicates that the estimated results may differ by the treatment group setting. The results of a set of robustness checks for age groups will be discussed in Sect. 7.5. 
Table 7.1 Test results for treatment group setting

\begin{tabular}{l|l|l|l|l}
\hline & \multicolumn{3}{l}{ Model 1: DID } & Model 2: DDD \\
\cline { 2 - 5 } & coef. & S.E. & coef. & S.E. \\
\hline Age 21 & -0.065 & 0.265 & -0.079 & 0.399 \\
\hline Age 22 & -0.116 & 0.194 & -0.259 & 0.305 \\
\hline Age 23 & -0.110 & 0.206 & -0.237 & 0.324 \\
\hline Age 24 & 0.123 & 0.164 & 0.272 & 0.259 \\
\hline Age 25 & -0.079 & 0.106 & -0.031 & 0.233 \\
\hline Age 26 & -0.015 & 0.125 & $0.610^{* *}$ & 0.271 \\
\hline Age 27 & 0.033 & 0.098 & 0.115 & 0.235 \\
\hline Age 28 & $0.220 * *$ & 0.095 & 0.106 & 0.238 \\
\hline Age 29 & 0.033 & 0.087 & 0.274 & 0.227 \\
\hline Age 30 & 0.058 & 0.084 & 0.151 & 0.220
\end{tabular}

Source Calculated based on CHNS 1989-2011

Note

(1) Note $* * * p<0.01, * * p<0.05, * p<0.10$

(2) The treatment group, age, year, male, health status, occupation, private sector, regular worker, urban hukou, province dummy variables are estimated, these results are not expressed in this table.

The DID item and DDD item coefficients are only shown in this table

\subsection{Results}

\subsubsection{The Impact of Higher Education Expansion Policy on the Wage of College Graduates}

The calculated results based on DID method are shown in Table 7.2. The treatment group is college graduates aged 21-25, the control group is college graduates aged 31-40. 2000 is the pre-period of policy implementation, and 2004, 2006, 2009, 2011 are the post-periods. The values of coefficients of DID items are from -0.109 to -3.447 , it is shown that the HEEP decreased the average wage level of young college graduate from 2004 to 2011. In addition, to compare with $2004(-0.114)$ and 2006 $(-0.109)$, the negative values are greater for $2009(-3.447)$ and $2011(-3.385)$. It indicates that the policy influences differ by the short term and the long term after the policy implementation.

The calculated results based on a DID method shown in Table 7.2 did not consider the other factors which may affect wage. When the other factors are controlled, does the higher education expansion policy affect the wage level of college graduates? Tables 7.3, 7.4 and 7.5 summarizes the econometric analysis results. Panel $\mathrm{A}$ is the results based on DID method, and Panel B is the results based on DDD method. The main findings are as follow:

First, based on the results shown in Table 7.3, the coefficients of DDD item are not statistically significant in both Panel A and Panel B. It indicates that, generally, the 
Table 7.2 Calculated result based on the DID method

\begin{tabular}{l|c|c|l}
\hline \multicolumn{4}{l|}{ Panel A } \\
\hline \multirow{2}{*}{ T: Treatment group } & $\mathrm{a}: 2000$ & $\mathrm{~b}: 2004$ & $\mathrm{D}(\mathrm{b}-\mathrm{a})$ \\
\cline { 2 - 4 } & $(10.685$ & 7.584 & -1.101 \\
\hline \multirow{2}{*}{ C: Control group } & 8.865 & $(4.640)$ & \\
\cline { 2 - 4 } & $(9.675)$ & 7.878 & -0.987 \\
\hline D(T-C) & -0.180 & -0.294 & -0.114
\end{tabular}

Panel B

\begin{tabular}{l|c|c|l}
\hline & $\mathrm{a}: 2000$ & $\mathrm{~b}: 2006$ & $\mathrm{D}(\mathrm{b}-\mathrm{a})$ \\
\hline \multirow{2}{*}{ T: Treatment group } & 8.685 & 8.360 & -0.325 \\
\cline { 2 - 4 } & $(10.000)$ & $(5.256)$ & \\
\hline \multirow{2}{*}{ : Control group } & 8.865 & 8.649 & -0.216 \\
\cline { 2 - 4 } & $(9.675)$ & $(11.857)$ & \\
\hline D(T-C) & -0.180 & -0.289 & -0.109 \\
\hline
\end{tabular}

Panel C

\begin{tabular}{l|c|c|c}
\hline & $\mathrm{a}: 2000$ & $\mathrm{~b}: 2009$ & $\mathrm{D}(\mathrm{b}-\mathrm{a})$ \\
\hline \multirow{2}{*}{ T: Treatment group } & 8.685 & 11.258 & 2.573 \\
\cline { 2 - 4 } & $(10.000)$ & $(7.168)$ & \\
\hline \multirow{2}{*}{ C: Control group } & 8.865 & 14.885 & 6.020 \\
\cline { 2 - 4 } & $(9.675)$ & $(28.312)$ & \\
\hline D(T-C) & -0.180 & -3.627 & -3.447 \\
\hline
\end{tabular}

Source Calculated based on CHNS 1989-2011 Note

(1) Values in parentheses are standard deviation

(2) Treatment group is the college graduates aged 21-25; Control group is the college graduates aged $31-40$

higher education expansion policy does not affect the average wage level of young college graduates.

The results based on the quantile regression model are shown in Table 7.4. For both low-wage (10th), middle-wage (30th, 60th) and high-wage (90th) groups, the coefficients of DID item are not statistically significant. It suggests that the difference of policy effect between various wage centile groups is small.

Finally, to compare the influence of the HEEP on wage by different periods (e.g. a short term, or a long term after the policy implementation), the year dummy variable is used and the results are summarized in Table 7.5. The results based on DID method indicates that the higher education expansion policy negatively affected wages in 2004, whereas the coefficients of DID items are not statistically significant for 2006, 2009 and 2011. It indicates that the HEEP may decrease the wage level of new college graduates in the short term, whereas the negative effect disappears in the long term. The reason for the results can be considered as follows. First, in the short term, 
Table 7.3 Results of the impact of the higher education expansion policy on the wage of college graduates

\begin{tabular}{|c|c|c|c|c|c|c|}
\hline \multicolumn{7}{|l|}{ Panel A: DID method } \\
\hline & \multicolumn{2}{|l|}{ Model 1} & \multicolumn{2}{|l|}{ Model 2} & \multicolumn{2}{|l|}{ Model 3} \\
\hline & coef. & S.E. & coef. & S.E. & coef. & S.E. \\
\hline Treatment & 0.146 & 0.455 & 0.386 & 0.445 & 0.096 & 0.203 \\
\hline Year & $0.683 * * *$ & 0.243 & $0.757 * * *$ & 0.219 & $0.586 * * *$ & 0.098 \\
\hline DID & -0.277 & 0.480 & -0.397 & 0.462 & -0.095 & 0.209 \\
\hline Exp. & -0.113 & 0.078 & -0.109 & 0.069 & -0.043 & 0.031 \\
\hline Exp-sq. & 0.008 & 0.007 & 0.008 & 0.006 & 0.004 & 0.003 \\
\hline Health & & & -0.006 & 0.028 & -0.007 & 0.013 \\
\hline Male & & & 0.087 & 0.163 & $0.121^{*}$ & 0.070 \\
\hline \multicolumn{7}{|l|}{ Occupation (Clerk) } \\
\hline Manager & & & 0.220 & 0.188 & $0.302 * * *$ & 0.080 \\
\hline Technician & & & -0.022 & 0.255 & 0.017 & 0.106 \\
\hline Agriculture & & & -0.119 & 1.013 & -0.044 & 0.682 \\
\hline Manufacturing job $(\mathrm{H})$ & & & -0.240 & 0.369 & -0.156 & 0.155 \\
\hline Manufacturing job (L) & & & -0.473 & 0.616 & -0.071 & 0.285 \\
\hline Service & & & 0.033 & 0.359 & 0.076 & 0.153 \\
\hline Others & & & 0.033 & 0.277 & 0.034 & 0.127 \\
\hline Regular worker & & & & & 0.022 & 0.079 \\
\hline Private sector & & & & & -0.034 & 0.143 \\
\hline Urban & & & & & $0.276 * * *$ & 0.076 \\
\hline \multicolumn{7}{|l|}{ Region (East) } \\
\hline Central & & & & & $-0.338 * * *$ & 0.103 \\
\hline West & & & & & $-0.289 * *$ & 0.129 \\
\hline Constants & 2.205 & 0.342 & 2.0124 & 0.378 & $1.792 * * *$ & 0.195 \\
\hline Inverse Mills ratio & -2.833 & 1.177 & -2.502 & 0.981 & $-1.030 * *$ & 0.518 \\
\hline Observations & 980 & & 980 & & 980 & \\
\hline Prob $>$ chi 2 & 0.0321 & & 0.056 & & 0.000 & \\
\hline
\end{tabular}

Panel B: DDD method

\begin{tabular}{l|l|l|l|l|l|l}
\hline & \multicolumn{4}{l}{ Model 1 } & \multicolumn{3}{l|}{ Model 2 } & Model 3 & \\
\cline { 2 - 7 } & coef. & S.E. & coef. & S.E. & coef. & S.E. \\
\hline Treatment & 0.038 & 0.407 & 0.140 & 0.430 & -0.006 & 0.404 \\
\hline Year & 0.234 & 0.215 & 0.277 & 0.215 & 0.005 & 0.209 \\
\hline College & 0.503 & 0.344 & 0.338 & 0.340 & 0.228 & 0.302 \\
\hline Year * College & 0.079 & 0.379 & 0.076 & 0.370 & 0.138 & 0.325 \\
\hline Year * Aged 21-25 & 0.113 & 0.489 & 0.128 & 0.524 & 0.234 & 0.475 \\
\hline
\end{tabular}


Table 7.3 (continued)

Panel B: DDD method

\begin{tabular}{|c|c|c|c|c|c|c|}
\hline & \multicolumn{2}{|l|}{ Model 1} & \multicolumn{2}{|l|}{ Model 2} & \multicolumn{2}{|l|}{ Model 3} \\
\hline & coef. & S.E. & coef. & S.E. & coef. & S.E. \\
\hline College * Aged 21-25 & -0.116 & 0.875 & 0.063 & 0.910 & -0.011 & 0.846 \\
\hline DDD & -0.146 & 1.015 & -0.345 & 1.061 & -0.200 & 0.963 \\
\hline Exp. & 0.019 & 0.059 & 0.010 & 0.058 & 0.019 & 0.052 \\
\hline Exp-sq. & -0.000 & 0.005 & 0.000 & 0.005 & 0.000 & 0.004 \\
\hline Health & & & -0.009 & 0.029 & -0.018 & 0.026 \\
\hline Male & & & -0.104 & 0.159 & -0.112 & 0.142 \\
\hline \multicolumn{7}{|l|}{ Occupation (Clerk) } \\
\hline Manager & & & 0.207 & 0.211 & 0.209 & 0.179 \\
\hline Technician & & & 0.125 & 0.284 & 0.120 & 0.241 \\
\hline Agriculture & & & 0.0111 & 0.436 & 0.037 & 0.471 \\
\hline Manufacturing job $(\mathrm{H})$ & & & -0.133 & 0.260 & -0.127 & 0.227 \\
\hline Manufacturing job (L) & & & -0.260 & 0.275 & -0.218 & 0.249 \\
\hline Service & & & -0.036 & 0.261 & -0.062 & 0.230 \\
\hline Others & & & -0.007 & 0.247 & 0.084 & 0.248 \\
\hline Regular worker & & & & & 0.021 & 0.142 \\
\hline Private sector & & & & & -0.013 & 0.272 \\
\hline Urban & & & & & -0.125 & 0.155 \\
\hline \multicolumn{7}{|l|}{ Region (East) } \\
\hline Central & & & & & -0.171 & 0.160 \\
\hline West & & & & & 0.048 & 0.224 \\
\hline Constants & $2.128 * * *$ & 0.342 & $2.324 * * *$ & 0.453 & $2.746 * * *$ & 0.455 \\
\hline Inverse Mills ratio & $-5.347 * * *$ & 1.526 & $-5.090 * * *$ & 1.385 & $-4.213 * * *$ & 1.088 \\
\hline Observations & 4,064 & & 4,064 & & 4,064 & \\
\hline Prob > chi 2 & 0.151 & & 0.547 & & 0.778 & \\
\hline
\end{tabular}

Source Calculated based on CHNS 1989-2011

Note

(1) $* * * p<0.01, * * p<0.05, * p<0.10$

(2) Heckman two step model is used. In the first step estimation, individual level variables including the age, health status, number of family members, gender, noearned income, urban hukou, region block (Central, Western Region), and region level variables including ratio of fixed asset investment to GDP, ratio of tertiary industry to GDP, ratio of trade to GDP, and GDP per capita are estimated, these results are not presented in this table

(3) In the second step examination, years of experience, health status, male, occupation, private sector, regular worker, urban, and region dummy variables are also estimated, these results are not presented in this table 
Table 7.4 Results of the impact of the higher education expansion policy on the wage of college graduates by wage centiles

\begin{tabular}{l|l|l|l|l}
\hline \multirow{2}{*}{ Treatment } & 10 th & 30 th & 60 th & 90 th \\
\hline \multirow{2}{*}{ Year } & 0.255 & 0.254 & 0.102 & -0.100 \\
\cline { 2 - 5 } & $(0.548)$ & $(0.207)$ & $(0.180)$ & $(0.341)$ \\
\hline \multirow{2}{*}{ DID } & $0.948^{* * *}$ & $0.720^{* *}$ & $0.630^{* * *}$ & $0.445^{* * *}$ \\
\cline { 2 - 5 } & $(0.241)$ & $(0.091)$ & $(0.079)$ & $(0.150)$ \\
\hline \multirow{2}{*}{ Inverse Mills ratio } & -0.097 & -0.028 & -0.0226 & -0.084 \\
\cline { 2 - 5 } & $(0.581)$ & $(0.220)$ & $(0.191)$ & $(0.362)$ \\
\hline Constants & $-3.009 *$ & $-2.779 * * *$ & $-3.005^{* * *}$ & $-2.617^{* * *}$ \\
\cline { 2 - 5 } & $(1.658)$ & $(0.627)$ & $(0.545)$ & $(1.032)$ \\
\hline Observations & 0.627 & $1.209^{* * *}$ & $1.859^{* * *}$ & $2.825^{* * *}$ \\
\hline Pseudo R2 & $(0.425)$ & $(0.161)$ & $(0.140)$ & $(0.265)$ \\
\hline \multirow{2}{*}{ Souce Cal } & 980 & 980 & 980 & 980 \\
\hline
\end{tabular}

Source Calculated based on CHNS 1989-2011

Note

(1) Note $* * * p<0.01, * * p<0.05, * p<0.10$

(2) The coefficients, standard error and statistical significances are summarized in this table

(3) Heckman two step model is used. In the first step estimation, individual level variables including the age, health status, number of family members, gender, noearned income, urban hukou, region block (Central, Western Region), and region level variables including ratio of fixed asset investment to GDP, ratio of tertiary industry to GDP, ratio of trade to GDP, and GDP per capita are estimated, these results are not presented in this table

(4) In the second step examination, years of experience, health status, male, occupation, private sector, regular worker, urban, and region dummy variables are also estimated, these results are not presented in this table

(5) The quantile regression model is used

here 2004, the great increase of college graduates from 0.95 million in 2000 to 2.39 million in 2004 became a great shock of labor supply of higher education workers, which may reduce the probability of labor participation for young college graduates and decrease the higher education graduate group's wage level. Second, in a long term, with economic growth and technological progress, labor supply and demand can be adjusted by the general equilibrium mechanism, and the negative effect of the policy may become smaller or disappear. 
Table 7.5 Results of period effect of the impact of higher education expansion policy on the wage of college graduates

Panel A: DID method

\begin{tabular}{l|l|l|l|l|l|l}
\hline & \multicolumn{3}{l}{ Model 1 } & \multicolumn{2}{l}{ Model 2 } & Model 3 \\
\cline { 2 - 7 } & coef. & S.E. & coef. & S.E. & coef. & S.E. \\
\hline Treatment & 0.145 & 0.436 & 0.376 & 0.417 & 0.076 & 0.180 \\
\hline Year & $0.690^{* * *}$ & 0.233 & $0.766^{* * *}$ & 0.205 & $0.607 * * *$ & 0.085 \\
\hline DIDy2004 & -0.585 & 0.620 & -0.777 & 0.574 & $-0.550^{* *}$ & 0.244 \\
\hline DIDy2006 & -0.388 & 0.586 & -0.576 & 0.559 & -0.279 & 0.235 \\
\hline DIDy2009 & -0.287 & 0.598 & -0.318 & 0.576 & 0.008 & 0.240 \\
\hline DIDy2011 & -0.085 & 0.523 & -0.180 & 0.493 & 0.151 & 0.209 \\
\hline Constants & $2.180 * * *$ & 0.329 & $1.985^{* * *}$ & 0.357 & $1.700^{* * *}$ & 0.171 \\
\hline Inverse Mills ratio & $-2.714 * *$ & 1.139 & $-2.341^{* *}$ & 0.937 & $-0.760 *$ & 0.456 \\
\hline Observations & 980 & & 980 & & 980 & \\
\hline Prob > chi2 & 0.082 & & 0.000 & & 0.000 & \\
\hline Pan & & & & & &
\end{tabular}

Panel B: DDD method

\begin{tabular}{l|l|l|l|l|l|l}
\hline & \multicolumn{4}{l}{ Model 1 } & \multicolumn{3}{l}{ Model 2 } & Model 3 & \\
\cline { 2 - 7 } & coef. & S.E. & coef. & S.E. & coef. & S.E. \\
\hline Treatment & 0.035 & 0.251 & 0.0992 & 0.259 & -0.057 & 0.221 \\
\hline College & 0.467 & 0.212 & 0.308 & 0.205 & 0.184 & 0.166 \\
\hline y2004 & 0.209 & 0.158 & 0.243 & 0.154 & -0.001 & 0.129 \\
\hline y2006 & 0.094 & 0.160 & 0.133 & 0.156 & -0.012 & 0.138 \\
\hline y2009 & $0.380 * * *$ & 0.175 & $0.447 * * *$ & 0.173 & 0.252 & 0.159 \\
\hline y2011 & $0.656 * * *$ & 0.187 & $0.720^{* * *}$ & 0.186 & $0.436 * *$ & 0.188 \\
\hline Year * College & 0.025 & 0.234 & 0.015 & 0.223 & 0.114 & 0.178 \\
\hline College * Aged & -0.033 & 0.540 & 0.134 & 0.548 & 0.067 & 0.463 \\
21-25 & & & & & & \\
\hline Year * Aged 21-25 & 0.099 & 0.302 & 0.107 & 0.315 & 0.233 & 0.260 \\
\hline DDDy2004 & -0.149 & 0.813 & -0.334 & 0.816 & -0.257 & 0.663 \\
\hline DDDy2006 & 0.088 & 0.784 & -0.150 & 0.810 & -0.083 & 0.647 \\
\hline DDDy2009 & -0.117 & 0.799 & -0.173 & 0.831 & -0.133 & 0.659 \\
\hline DDDy2011 & -0.220 & 0.696 & -0.360 & 0.704 & -0.227 & 0.571 \\
\hline Constants & $1.769 * * *$ & 0.240 & $1.876 * * *$ & 0.307 & $2.131 * * *$ & 0.326 \\
\hline Inverse Mills ratio & $-3.296 * * *$ & 1.137 & $-3.060 * * *$ & 1.029 & $-2.302 * * *$ & 0.872 \\
\hline Observations & 4,046 & & 4,046 & & 4,046 & \\
\hline
\end{tabular}


Table 7.5 (continued)

Panel B: DDD method

\begin{tabular}{l|l|l|l|l|l|l}
\hline & \multicolumn{2}{l|}{ Model 1 } & \multicolumn{2}{l|}{ Model 2 } & \multicolumn{2}{l}{ Model 3 } \\
\cline { 2 - 7 } & coef. & S.E. & coef. & S.E. & coef. & S.E. \\
\hline Prob > chi2 & 0.000 & & 0.000 & & 0.000 & \\
\hline
\end{tabular}

Source Calculated based on CHNS 1989-2011

Note

(1) $* * * p<0.01, * * p<0.05, * p<0.10$

(2) Heckman two step model is used. In the first step estimation, individual level variables including the age, health status, number of family members, gender, noearned income, urban hukou, region block (Central, Western Region), and region level variables including ratio of fixed asset investment to GDP, ratio of tertiary industry to GDP, ratio of trade to GDP, and GDP per capita are estimated, these results are not presented in this table

(3) In the second step examination, years of experience, health status, male, occupation, private sector, regular worker, urban, and region dummy variables are also estimated, these results are not presented in this table

\subsubsection{The Results of the Impact of the Higher Education Expansion Policy on Wage by Gender}

Does the impact of the HEEP differ by males and females? The results by gender are summarized in Table 7.6. It indicates that in both male and female groups, the impacts of the policy on wage are not statistically significant. It indicates that the

Table 7.6 Results of the impact of higher education expansion policy on wage by gender

\begin{tabular}{|c|c|c|c|c|}
\hline \multicolumn{5}{|c|}{ Panel A: DID method } \\
\hline & \multicolumn{2}{|l|}{ Female } & \multicolumn{2}{|l|}{ Male } \\
\hline & coef. & S.E. & coef. & S.E. \\
\hline Treatment & 0.290 & 0.323 & 0.035 & 0.252 \\
\hline Year & $0.622 * * *$ & 0.138 & $0.641 * * *$ & 0.127 \\
\hline DID & -0.255 & 0.344 & -0.060 & 0.264 \\
\hline Constants & $1.655 * * *$ & 0.249 & $1.829 * * *$ & 0.236 \\
\hline Inverse Mills ratio & $-1.011 * *$ & 0.470 & 0.247 & 0.612 \\
\hline Observations & 408 & & 572 & \\
\hline Prob > chi 2 & 0.000 & & 0.000 & \\
\hline
\end{tabular}

Panel B: DDD method

\begin{tabular}{l|l|l|l|l}
\hline & \multicolumn{2}{|l|}{} & \multicolumn{2}{l}{ Male } \\
\cline { 2 - 5 } & Female & S.E. & coef. & S.E. \\
\hline Treatment & -0.144 & 0.671 & 0.069 & 0.428 \\
\hline Year & -0.096 & 0.376 & 0.085 & 0.213 \\
\hline College & 0.289 & 0.523 & 0.162 & 0.313 \\
\hline
\end{tabular}


Table 7.6 (continued)

\begin{tabular}{|c|c|c|c|c|}
\hline \multicolumn{5}{|l|}{ Panel B: DDD method } \\
\hline & \multicolumn{2}{|l|}{ Female } & \multicolumn{2}{|l|}{ Male } \\
\hline & coef. & S.E. & coef. & S.E. \\
\hline Year * College & 0.086 & 0.553 & 0.222 & 0.340 \\
\hline Year * Aged 21-25 & 0.077 & 1.570 & -0.045 & 0.842 \\
\hline College * Aged 21-25 & 0.298 & 0.784 & 0.206 & 0.507 \\
\hline DDD & -0.270 & 1.748 & -0.189 & 0.973 \\
\hline Constants & 2.943 & 2.301 & $2.235^{*}$ & 1.200 \\
\hline Inverse Mills ratio & -1.446 & 1.615 & -0.394 & 1.520 \\
\hline Observations & 1,722 & & 2,342 & \\
\hline Prob > chi 2 & 0.999 & & 0.690 & \\
\hline
\end{tabular}

Source Calculated based on CHNS 1989-2011

Note

(1) Note ***p $<0.01, * * p<0.05, * p<0.10$

(2) Heckman two step model is used. In the first step estimation, individual level variables including the age, health status, number of family members, gender, noearned income, urban hukou, region block (Central, Western Region), and region level variables including ratio of fixed asset investment to GDP, ratio of tertiary industry to GDP, ratio of trade to GDP, and GDP per capita are estimated, these results are not presented in this table

(3) In the second step examination, years of experience, health status, occupation, private sector, regular worker, urban, and region dummy variables are also estimated, these results are not presented in this table

gender disparities of the influence of the HEEP on wage is small. It may be caused by that the gender gap for the young college group is smaller than for the middle age or older age groups.

\subsubsection{The Results of the Impact of the Higher Education Expansion Policy on Wage by Region and Hukou Groups}

\section{(1) The results by region}

Table 7.7 summarizes the results by Eastern Region and no-Eastern Region (Westernand Central Region). It is shown that although the policy effect is a negative value for the Eastern Region and a positive value for the no-Eastern Region, these results are not statistically significant. The results indicate that the difference of the impact of the policy on college graduates wage between Eastern, Central and Western Region groups is small.

Two reasons may be considered for the results. First, during the 2000s, the Chinese government promoted the economic development in the Western, and 
Table 7.7 Results of the impact of the higher education expansion policy on wage by region

Panel A: DID method

\begin{tabular}{l|l|l|l|l}
\hline \multirow{2}{*}{} & \multicolumn{3}{l|}{ East } & Central/West \\
\cline { 2 - 5 } & coef. & S.E. & coef. & S.E. \\
\hline Treatment & 0.165 & 0.916 & -0.050 & 0.253 \\
\hline Year & 0.397 & 0.466 & $0.502^{* * * *}$ & 0.116 \\
\hline DID & -0.060 & 0.933 & 0.221 & 0.295 \\
\hline Constants & $2.401^{* * *}$ & 0.861 & $1.361^{* * *}$ & 0.260 \\
\hline Inverse Mills ratio & -2.740 & 2.035 & -0.172 & 0.390 \\
\hline Observations & 533 & & 447 & \\
\hline Prob > chi2 & 0.000 & & 0.000 & \\
\hline
\end{tabular}

Panel B: DDD method

\begin{tabular}{l|l|l|l|l}
\hline & \multicolumn{2}{l}{ East } & \multicolumn{2}{l}{ Central/West } \\
\cline { 2 - 5 } & coef. & S.E. & coef. & S.E. \\
\hline Treatment & 0.197 & 0.577 & -0.097 & 0.187 \\
\hline Year & 0.045 & 0.321 & $0.213 * *$ & 0.090 \\
\hline College & 0.321 & 0.439 & 0.169 & 0.137 \\
\hline Year * College & 0.049 & 0.460 & 0.175 & 0.151 \\
\hline Year * Aged 21-25 & -0.022 & 1.113 & 0.067 & 0.397 \\
\hline College * Aged 21-25 & -0.039 & 0.662 & 0.415 & 0.222 \\
\hline DDD & -0.111 & 1.235 & -0.313 & 0.466 \\
\hline Constants & $2.880 * * *$ & 0.579 & $1.637 * * *$ & 0.202 \\
\hline Inverse Mills ratio & $-3.359^{* * *}$ & 1.077 & $-1.572 * * *$ & 0.450 \\
\hline Observations & 1,712 & & 2,352 & \\
\hline Prob $>$ chi2 & 0.796 & & 0.000 &
\end{tabular}

Source Calculated based on CHNS 1989-2011

Note

(1) Note ***p $p<0.01, * * p<0.05, * p<0.10$

(2) Heckman two step model is used. In the first step estimation, individual level variables including the age, health status, number of family members, gender, noearned income, urban hukou, region block (Central, Western Region), and region level variables including ratio of fixed asset investment to GDP, ratio of tertiary industry to GDP, ratio of trade to GDP, and GDP per capita are estimated, these results are not presented in this table

(3) In the second step examination, years of experience, health status, male, occupation, private sector, regular worker, and urban dummy variables are also estimated, these results are not presented in this table

Central Regions to reduce the regional disparity, and the GDP growth rate became greater for the Western and Central Regions than for the Eastern Region. For example, the GDP growth rate was $7.8 \%$ for the Western Region, $10.5 \%$ for the Central Region, and 7.2\% for the Eastern Region in 2009 (NBS 2010). Currently, economic growth in Western and Central Regions may increase the college graduate labor demand in 
these regions. Second, with the deregulation of the registration system, labor migrations between various regions became easier during the 2000s. Labor migration may cause the various regional wage levels convergence.

\section{(2) The results by hukou type}

It is known that in China there remains the discrimination against migrants by the Hukou system, and there persists the wage gap between the local urban hukou residents and the migrants with rural hukou in Chinese urban labor market. The analyses for the rural hukou group and urban hukou group are summarized in Table 7.8. It suggests that the policy positively affects the wage of the migrants (Panel A); whereas, the policy negatively affects the wage of the local urban hukou residents (Panel B).

The reasons can be considered as follows. First, because there remains the discrimination against migrants during both the pre-policy period and the post-policy period, the wage is lower and the wage rise is smaller for the migrants (Ma 2018c). When there maintains the discrimination against migrants, even after the HEEP was implemented, for the migrant group, the wage gap of college graduates aged 21-25 and the group aged 31-40, the wage gap between the college graduates and the senior high school graduates, and the wage gap between pre-policy and post-policy may be smaller than those for the urban residents. Therefore, the results in Panel A show that the policy only negatively influenced the wage of local urban residents. Second, when the human capital and other factors are constant, because the average wage level is lower for migrants than local urban hukou residents, the labor demand for migrants may increase, which causes the migrant college graduates' wage rise during the postpolicy period. Therefore, as it is shown in Panel B, the policy positively affected the

Table 7.8 Results of the impact of higher education expansion policy on employment by hukou type Panel A: DID method

\begin{tabular}{l|l|l|l|l}
\hline \multirow{2}{*}{} & \multicolumn{2}{l}{ Urban } & \multicolumn{2}{l}{ Rural } \\
\cline { 2 - 5 } & coef. & S.E. & coef. & S.E. \\
\hline Treatment & 0.213 & 0.210 & -0.538 & 0.344 \\
\hline Year & $0.633 * * *$ & 0.108 & $0.406 * * *$ & 0.135 \\
\hline DID & -0.301 & 0.221 & $0.819 * *$ & 0.374 \\
\hline Constants & $1.975 * * *$ & 0.180 & $1.514 * * *$ & 0.291 \\
\hline Inverse Mills ratio & $-0.792 *$ & 0.515 & -0.009 & 0.421 \\
\hline Observations & 645 & & 335 & \\
\hline Prob $>$ chi2 & 0.000 & & 0.000 &
\end{tabular}

Panel B: DDD method

\begin{tabular}{l|l|l|l|l}
\hline \multirow{2}{*}{} & \multicolumn{2}{|l|}{ Urban } & \multicolumn{2}{l}{ Rural } \\
\cline { 2 - 5 } & coef. & S.E. & coef. & S.E. \\
\hline Treatment & 0.126 & 0.130 & -0.0133 & 0.401 \\
\hline Year & $0.187^{* *}$ & 0.080 & 0.144 & 0.182 \\
\hline \multicolumn{4}{l}{ (continued) }
\end{tabular}


Table 7.8 (continued)

\begin{tabular}{|c|c|c|c|c|}
\hline \multicolumn{5}{|l|}{ Panel B: DDD method } \\
\hline & \multicolumn{2}{|l|}{ Urban } & \multicolumn{2}{|l|}{ Rural } \\
\hline & coef. & S.E. & coef. & S.E. \\
\hline University & $0.490 * * *$ & 0.106 & 0.267 & 0.323 \\
\hline Year * University & -0.018 & 0.163 & -0.007 & 0.346 \\
\hline Year* Aged 21-25 & 0.309 & 0.346 & -0.555 & 1.010 \\
\hline University * Aged 21-25 & $-0.700 * * *$ & 0.182 & 0.242 & 0.449 \\
\hline DDD & $-0.008^{*}$ & 0.238 & 0.451 & 1.123 \\
\hline Constants & $1.975 * * *$ & 0.180 & $2.819 * * *$ & 0.883 \\
\hline Inverse Mills ratio & $-0.792^{*}$ & 0.515 & $-2.850 * * *$ & 0.788 \\
\hline Observations & 2,342 & & 1,857 & \\
\hline Prob > chi 2 & 0.690 & & 0.432 & \\
\hline
\end{tabular}

Source Calculated based on CHNS 1989-2011

Note

(1) Note $* * * p<0.01, * * p<0.05, * p<0.10$

(2) Heckman two step model is used. In the first step estimation, individual level variables including the age, health status, number of family members, gender, noearned income, urban hukou, region block (Central, Western Region), and region level variables including ratio of fixed asset investment to GDP, ratio of tertiary industry to GDP, ratio of trade to GDP, and GDP per capita are estimated, these results are not presented in this table

(3) In the second step examination, years of experience, health status, male, occupation, private sector, regular worker, and region dummy variables are also estimated, these results are not presented in this table

wage of migrant groups. It indicates that there may remain the substitutions of labor demand for the young college graduates between the migrants and local urban hukou residents. More detailed study is needed on this issue.

\subsubsection{Robustness Checks}

\section{(1) Using various treatment groups}

Two types of treatment groups are used to investigate if the policy effect varies by treatment group constructions. The results are summarized at Table 7.9. Estimation 1 is the analysis using the college graduates aged 21-27 as the treatment group. Estimation 2 is the analysis using the college graduate aged 21-30 as the treatment group. It is found that the results for these two varied treatment groups are similar: the policy effects are not statistically significant. In comparison with the results of Panel A in Table 7.3 which uses the same model, it is indicated that the estimated results are sensitive for the treatment group setting. 
Table 7.9 Results using various treatment groups

Estimation 1

\begin{tabular}{|c|c|c|c|c|c|c|}
\hline & \multicolumn{2}{|l|}{ Model 1} & \multicolumn{2}{|l|}{ Model 2} & \multicolumn{2}{|l|}{ Model 3} \\
\hline & coef. & S.E. & coef. & S.E. & coef. & S.E. \\
\hline Treatment & 0.010 & 0.397 & 0.182 & 0.389 & -0.016 & 0.156 \\
\hline Year & $0.675 * * *$ & 0.251 & $0.751 * * *$ & 0.233 & $0.594 * * *$ & 0.096 \\
\hline DID & -0.225 & 0.415 & -0.309 & 0.404 & -0.073 & 0.163 \\
\hline Exp. & -0.093 & 0.077 & -0.092 & 0.071 & -0.035 & 0.029 \\
\hline Exp-sq. & 0.007 & 0.007 & 0.007 & 0.007 & 0.004 & 0.003 \\
\hline Health & & & -0.007 & 0.028 & -0.009 & 0.012 \\
\hline Male & & & 0.078 & 0.162 & $0.110^{*}$ & 0.064 \\
\hline \multicolumn{7}{|l|}{ Occupation (Clerk) } \\
\hline Manager & & & 0.235 & 0.186 & $0.3054 * * *$ & 0.073 \\
\hline Technician & & & 0.016 & 0.251 & 0.042 & 0.097 \\
\hline Agri. & & & -0.095 & 1.077 & -0.036 & 0.670 \\
\hline Manufacturing job $(\mathrm{H})$ & & & -0.239 & 0.379 & -0.170 & 0.147 \\
\hline Manufacturing job (L) & & & -0.256 & 0.541 & 0.041 & 0.228 \\
\hline Service & & & -0.008 & 0.363 & 0.013 & 0.142 \\
\hline Others & & & 0.061 & 0.277 & 0.065 & 0.118 \\
\hline Regular worker & & & & & 0.002 & 0.073 \\
\hline Private sector & & & & & -0.046 & 0.129 \\
\hline Urban & & & & & $0.252 * * *$ & 0.071 \\
\hline \multicolumn{7}{|l|}{ Region (East) } \\
\hline Central & & & & & $-0.325 * * *$ & 0.099 \\
\hline West & & & & & $-0.231 * *$ & 0.111 \\
\hline Constants & $2.167 * * *$ & 0.346 & $1.984 * * *$ & 0.390 & $1.797 * * *$ & 0.187 \\
\hline Inverse Mills ratio & $-2.912 * *$ & 1.307 & $-2.662 * *$ & 1.137 & $-1.015^{*}$ & 0.580 \\
\hline Observations & 1,116 & & 1,116 & & 1,116 & \\
\hline Prob > chi 2 & 0.057 & & 0.066 & & 0.000 & \\
\hline
\end{tabular}

Estimation 2

\begin{tabular}{l|l|l|l|l|l|l}
\hline & \multicolumn{2}{l}{ Model 1 } & \multicolumn{2}{l}{ Model 2 } & \multicolumn{2}{l}{ Model 3 } \\
\cline { 2 - 7 } & coef. & S.E. & coef. & S.E. & coef. & S.E. \\
\hline Treatment & 0.010 & 0.397 & 0.223 & 0.463 & 0.046 & 0.286 \\
\hline Year & $0.675^{*} * *$ & 0.251 & $0.710 * *$ & 0.329 & 0.554 & 0.207 \\
\hline DID & -0.225 & 0.415 & -0.213 & 0.480 & -0.027 & 0.297 \\
\hline Exp. & -0.093 & 0.077 & -0.055 & 0.095 & -0.024 & 0.058 \\
\hline Exp-sq. & 0.007 & 0.007 & 0.004 & 0.009 & 0.003 & 0.006 \\
\hline Health & & & -0.008 & 0.035 & -0.009 & 0.022 \\
\hline
\end{tabular}


Table 7.9 (continued)

\begin{tabular}{|c|c|c|c|c|c|c|}
\hline \multicolumn{7}{|l|}{ Estimation 2} \\
\hline & \multicolumn{2}{|l|}{ Model 1} & \multicolumn{2}{|l|}{ Model 2} & \multicolumn{2}{|l|}{ Model 3} \\
\hline & coef. & S.E. & coef. & S.E. & coef. & S.E. \\
\hline Male & & & 0.039 & 0.205 & 0.055 & 0.125 \\
\hline \multicolumn{7}{|l|}{ Occupation (Clerk) } \\
\hline Manager & & & 0.251 & 0.235 & $0.295 * *$ & 0.141 \\
\hline Technician & & & 0.056 & 0.320 & 0.070 & 0.189 \\
\hline Agri. & & & 0.239 & 1.262 & 0.066 & 1.120 \\
\hline Manufacturing job $(\mathrm{H})$ & & & -0.182 & 0.462 & -0.142 & 0.276 \\
\hline Manufacturing job (L) & & & -0.317 & 0.664 & -0.072 & 0.435 \\
\hline Service & & & -0.073 & 0.461 & -0.074 & 0.274 \\
\hline Others & & & 0.090 & 0.360 & 0.080 & 0.233 \\
\hline Regular worker & & & & & 0.015 & 0.138 \\
\hline Private sector & & & & & -0.029 & 0.265 \\
\hline Urban & & & & & 0.162 & 0.135 \\
\hline \multicolumn{7}{|l|}{ Region (East) } \\
\hline Central & & & & & -0.246 & 0.207 \\
\hline West & & & & & -0.161 & 0.228 \\
\hline Constants & $2.167 * * *$ & 0.346 & $2.040 * * *$ & 0.509 & $1.975^{* * *}$ & 0.362 \\
\hline Inverse Mills ratio & $-2.912 * *$ & 1.307 & $-3.766 * * *$ & 1.741 & -2.201 & 1.413 \\
\hline Observations & 1,454 & & 1,454 & & 1,454 & \\
\hline Prob $>$ chi 2 & 0.531 & & 0.872 & & 0.872 & \\
\hline
\end{tabular}

Source Calculated based on CHNS 1989-2011

Note

(1) Note $* * * p<0.01, * * p<0.05, * p<0.10$

(2) Heckman two step model is used. In the first step estimation, individual level variables including the age, health status, number of family members, gender, noearned income, urban hukou, region block (Central, Western Region), and region level variables including ratio of fixed asset investment to GDP, ratio of tertiary industry to GDP, ratio of trade to GDP, and GDP per capita are estimated, these results are not presented in this table

(3) In the second step examination, years of experience, health status, male, occupation, private sector, regular worker, urban, and region dummy variables are also estimated, these results are not presented in this table

Why is the policy effect different for the college graduate group aged $21-25$, and the group aged 21-27 or the group aged 21-30? It can be thought that a new college graduate aged from 21-25 searches for his (her) work in the first career period. When the labor demand is consistent, the increase of new college graduates labor supply may reduce the wage level of this group easily and quickly. Thus the results for the policy impact is more sensitive for the young college graduates who are aged 21-25 than for the group aged 21-27 or aged 21-30 years old. 


\section{(2) The Placebo test}

A placebo test is used to test the propriety of the DID/DDD methods used in the study. It is thought that the higher education expansion policy greatly affects the college graduate labor supply, whereas the influence of the policy on senior high school graduates is smaller. Therefore, when the senior high school graduate sample is used to take a similar analysis based on the DID method, the results should be different to that shown in Panel A of Table 7.3. In the placebo test, the treatment group is defined as the senior high school graduates aged 21-25, and the treatment group is defined as the senior high school graduates aged 31-40. The results are summarized in Table 7.10. It is found that the whole coefficients of DID items are not statistically significant. It is clearly that these results are different from those shown in Table 7.3.

Table 7.10 Results of the placebo test

\begin{tabular}{|c|c|c|c|c|c|c|}
\hline & \multicolumn{2}{|l|}{ Model 1} & \multicolumn{2}{|l|}{ Model 2} & \multicolumn{2}{|l|}{ Model 3} \\
\hline & coef. & S.E. & coef. & S.E. & coef. & S.E. \\
\hline Treatment & -0.539 & 0.416 & -0.318 & 0.413 & -0.342 & 0.394 \\
\hline Year & 0.174 & 0.171 & 0.250 & 0.166 & 0.048 & 0.175 \\
\hline DID & 0.237 & 0.306 & 0.206 & 0.313 & 0.223 & 0.304 \\
\hline Exp. & -0.073 & 0.087 & -0.061 & 0.086 & -0.039 & 0.081 \\
\hline Exp-sq. & 0.001 & 0.006 & 0.000 & 0.005 & 0.000 & 0.005 \\
\hline Health & & & -0.008 & 0.027 & -0.023 & 0.027 \\
\hline Male & & & -0.115 & 0.143 & -0.146 & 0.140 \\
\hline \multicolumn{7}{|l|}{ Occupation (Clerk) } \\
\hline Manager & & & 0.096 & 0.206 & 0.106 & 0.190 \\
\hline Technician & & & 0.240 & 0.269 & 0.177 & 0.247 \\
\hline Agriculture & & & -0.013 & 0.313 & 0.106 & 0.368 \\
\hline Manufacturing job $(\mathrm{H})$ & & & -0.129 & 0.213 & -0.125 & 0.201 \\
\hline Manufacturing job (L) & & & -0.232 & 0.218 & -0.238 & 0.209 \\
\hline Service & & & 0.004 & 0.213 & -0.048 & 0.206 \\
\hline Others & & & -0.042 & 0.212 & 0.057 & 0.232 \\
\hline Regular worker & & & & & -0.008 & 0.131 \\
\hline Private sector & & & & & -0.055 & 0.234 \\
\hline Urban & & & & & -0.075 & 0.151 \\
\hline \multicolumn{7}{|l|}{ Region (East) } \\
\hline Central & & & & & -0.218 & 0.149 \\
\hline West & & & & & 0.070 & 0.203 \\
\hline Constants & $2.653 * * *$ & 0.471 & $2.720 * * *$ & 0.565 & $3.125 * * *$ & 0.596 \\
\hline
\end{tabular}


Table 7.10 (continued)

\begin{tabular}{l|l|l|l|l|l|l}
\hline & \multicolumn{3}{|l|}{ Model 1 } & \multicolumn{2}{l|}{ Model 2 } & Model 3 \\
\cline { 2 - 7 } & coef. & S.E. & coef. & S.E. & coef. & S.E. \\
\hline Inverse Mills ratio & $-3.375^{* * *}$ & 0.990 & $-3.113^{* * *}$ & 0.926 & $-2.757 * * *$ & 0.775 \\
\hline Observations & 1,892 & & 1,892 & & 1,892 & \\
\hline Prob > chi2 & 0.0276 & & 0.094 & & 0.807 & \\
\hline
\end{tabular}

Source Calculated based on CHNS 1989-2011

Note

(1) Note $* * * p<0.01, * * p<0.05, * p<0.10$

(2) Treatment group: senior high school graduates aged from 21 to 30 years old; Control group: senior high school graduates aged from 31 to 40 years old

(3) Heckman two step model is used. In the first step estimation, individual level variables including the age, health status, number of family members, gender, noearned income, urban hukou, region block (Central, Western Region), and region level variables including ratio of fixed asset investment to GDP, ratio of tertiary industry to GDP, ratio of trade to GDP, and GDP per capita are estimated, these results are not presented in this table

(4) In the second step examination, years of experience, health status, male, occupation, private sector, regular worker, urban, and region dummy variables are also estimated, these results are not presented in this table

\subsection{Conclusions}

In 1999, the Chinese government implemented a Higher Education Expansion Policy (HEEP). With the implementation of the policy, new college graduates increased yearly from 0.8 million to 6.1 million from 1999 to 2011 (NBS 2016). It is thought this dramatic increase in the college graduate labor supply may affect the wage level of young college graduates. Based on the quasi-natural experiment methods (DID method and DDD method, using six waves (1997, 2000, 2004, 2006, 2009, and 2011) longitudinal survey data from the Chinese Health and Nutrition Survey (CHNS), this study employs an empirical study to provide new evidences on the issue.

Five major conclusions emerge. First, in general, the HEEP does not affect the wage level of young college graduates; the difference of policy impact on wage by various wage centiles is small; the HEEP decreased the wage level of new college graduates in the short term (in 2004); whereas the negative effect disappears in the long term (in 2006, 2009, and 2011). Second, the gender disparity of the impact of the HEEP on wage levels of young college graduates is small. Third, the regional disparity of the influence of the policy on wage between Eastern Region and NonEastern Region (Central Region, Western Region) is small. But there maintains a larger difference of the policy effect between urban hukou group and rural hukou group. Concretely, the policy positively affects the wage of the migrants most of whom are with the rural Hukou, whereas the policy negatively affects the wage of the local urban Hukou residents. Fourth, the robustness checks confirms these results.

Based on these empirical study results, it suggests that although the gender differences of the impact of the policy on the wage level of new college graduates is smaller, for both female and male workers, in a short term, the policy may affect the 
wage level of new college graduates, but in a long-term, the negative effect of the policy on wages may disappear. Wolf (2002), De Meulemeester and Rochat (1995) argued that higher education can contribute to economic growth by training intellectuals and facilitating scientific and technological innovation, or if the content of the courses is directed towards a productive objective. It indicates that from a long-term perspective, with economic growth and technological innovation, the labor demand for highly-educated labor should increase, and as a result the increase of college graduates supply can be absorbed. An important issue for the government is to promote the economic growth through the implementation of the HEEP and to upgrade industry structure based on the technological innovation.

\section{Notes}

1. In China there are two types of colleges: colleges with three years of study course, and universities with four or five years of study course. In the study, the two types are referred to simply as "college".

2. In China, college includes regular college and irregular college (such as colleges which provide education courses at night, or colleges which provide the education courses by television communication).

3. For the impact of higher education expansion policy on employment, please refer to Wu and Zhao (2010), Xing and Li (2011), Li et al. (2014), Yao et al. (2013), Knight et al. (2017) and Ma (2018a).

4. Regional level variables are obtained from the China Statistics Yearbook in each survey year.

\section{Appendix}

See Table 7.11.

Table 7.11 Descriptive statistics of variables

\begin{tabular}{l|l|l|l|l|l|l|l}
\hline & \multicolumn{2}{l}{$\begin{array}{l}\text { College aged } \\
21-25\end{array}$} & \multicolumn{2}{l}{$\begin{array}{l}\text { College aged } \\
\text { 31-40 }\end{array}$} & \multicolumn{2}{l}{$\begin{array}{l}\text { Senior high aged } \\
21-25\end{array}$} \\
\cline { 2 - 9 } & Mean & S.D. & Mean & S.D. & Mean & S.D. \\
\hline log.hourly wage & 2.282 & 0.754 & 2.337 & 0.929 & 1.730 & 0.799 \\
\hline Exp & 8 & 1 & 19 & 3 & 11 & 1 \\
\hline Number of family members & 4 & 1 & 4 & 1 & 4 & 1 \\
\hline Health status & 6.842 & 2.662 & 5.905 & 2.935 & 6.434 & 2.591 \\
\hline Male & 0.596 & 0.492 & 0.586 & 0.493 & 0.549 & 0.498 \\
\hline Noearned income & 48,077 & 90,626 & 38,849 & 41,826 & 32,475 & 50,876 \\
\hline & & & & \multicolumn{4}{c}{ (continued) }
\end{tabular}


Table 7.11 (continued)

\begin{tabular}{|c|c|c|c|c|c|c|}
\hline & \multicolumn{2}{|c|}{$\begin{array}{l}\text { College aged } \\
21-25\end{array}$} & \multicolumn{2}{|c|}{$\begin{array}{l}\text { College aged } \\
31-40\end{array}$} & \multicolumn{2}{|c|}{$\begin{array}{l}\text { Senior high aged } \\
21-25\end{array}$} \\
\hline & Mean & S.D. & Mean & S.D. & Mean & S.D. \\
\hline \multicolumn{7}{|l|}{ Occupation } \\
\hline Manager & 0.247 & 0.433 & 0.459 & 0.499 & 0.103 & 0.304 \\
\hline Technician & 0.075 & 0.265 & 0.139 & 0.347 & 0.029 & 0.169 \\
\hline Clerk & 0.411 & 0.494 & 0.228 & 0.420 & 0.190 & 0.393 \\
\hline Agri. & 0.000 & 0.000 & 0.003 & 0.051 & 0.026 & 0.158 \\
\hline Manufacturing job $(\mathrm{H})$ & 0.055 & 0.228 & 0.045 & 0.207 & 0.205 & 0.405 \\
\hline Manufacturing job (L) & 0.021 & 0.142 & 0.011 & 0.102 & 0.136 & 0.343 \\
\hline Service & 0.082 & 0.276 & 0.045 & 0.207 & 0.223 & 0.417 \\
\hline Others & 0.110 & 0.313 & 0.071 & 0.257 & 0.088 & 0.284 \\
\hline Regular worker & 0.568 & 0.497 & 0.793 & 0.405 & 0.458 & 0.499 \\
\hline Private sector & 0.123 & 0.330 & 0.038 & 0.192 & 0.040 & 0.197 \\
\hline Urban hukou & 0.699 & 0.460 & 0.657 & 0.475 & 0.520 & 0.501 \\
\hline \multicolumn{7}{|l|}{ Region } \\
\hline East & 0.664 & 0.474 & 0.613 & 0.487 & 0.505 & 0.501 \\
\hline Central & 0.288 & 0.454 & 0.284 & 0.451 & 0.333 & 0.472 \\
\hline West & 0.048 & 0.214 & 0.103 & 0.304 & 0.161 & 0.368 \\
\hline \multicolumn{7}{|l|}{ Regional level variables } \\
\hline Ratio of fixed asset investment to GDP & 0.417 & 0.147 & 0.426 & 0.162 & 0.447 & 0.164 \\
\hline Ratio of trade to GDP & 0.422 & 0.155 & 0.454 & 0.178 & 0.340 & 0.079 \\
\hline Ratio of tertiary industry to GDP & 0.513 & 0.524 & 0.453 & 0.452 & 0.257 & 0.286 \\
\hline GDP per capita & 39,424 & 30,197 & 43,018 & 30,097 & 23,130 & 20,092 \\
\hline \multicolumn{7}{|l|}{ Survey year } \\
\hline y1997 & 0.096 & 0.295 & 0.061 & 0.239 & 0.198 & 0.399 \\
\hline y2000 & 0.068 & 0.253 & 0.107 & 0.309 & 0.172 & 0.378 \\
\hline y2004 & 0.137 & 0.345 & 0.093 & 0.291 & 0.139 & 0.347 \\
\hline y2006 & 0.158 & 0.366 & 0.113 & 0.317 & 0.099 & 0.299 \\
\hline y2009 & 0.151 & 0.359 & 0.112 & 0.315 & 0.147 & 0.354 \\
\hline y2011 & 0.390 & 0.490 & 0.514 & 0.500 & 0.245 & 0.431 \\
\hline
\end{tabular}

Source Calculated based on CHNS 1989-2011

Note Calculated based on total samples including females and males

\section{References}

Becker, G. S. (1964). Human capital: A theoretical and empirical analysis, with special reference to education. New York: Columbia University Press.

Chang, J., \& Xiang, F. (2013). Higher education expansion and return to college education. Chinese Journal of Population Science, 3, 104-111 (In Chinese). 
De Meulemeester, J., \& Rochat, D. (1995). A causality of the link between higher education and economic development. Economics of Education Review, 14(4), 351-361.

Gao, W., \& Smyth, R. (2015). Education expansion and returns to schooling in urban China, 20012010: Evidence from three waves of the China Urban Labor Survey. Journal of the Asia Pacific Economy, 20(2), 178-201.

Gustafsson, B., \& Li, S. (2000). Economic transformation and the gender earnings gap in urban China. Journal of Population Economics, 13(2), 305-329.

He, Y. (2009). The changes of the rate of return to education: An empirical study based on the data of CHNS. Chinese Journal of Population Science, 2, 44-54 (In Chinese).

Heckman, J. J. (1979). Sample selection bias as a specification error. Econometrica, 47(1), 153-161.

Knight, J., Deng, Q., \& Li, S. (2017). China's expansion of higher education: The labor market consequences of a supply shock. China Economic Review, 43(C), 127-141.

Li, S., \& Ma, X. (2006). Occupational segregation and gender wage differentials in urban China. Chinese Journal of Population Science, 5, 1-14 (In Chinese).

$\mathrm{Li}, \mathrm{S} .$, \& Ma, X. (2015). Impact of minimum wage on gender wage gaps in urban China. IZA Journal of Labor and Development, 4, 20.

Li, S., Whalle, J., \& Xing, C. (2014). China's higher education expansion and unemployment of college graduates. China Economic Review, 30, 567-582.

Ma, C., Gu, H., \& Li, J. (2013). Change of gender wage gaps in Chinese labor market: Evidence from quantile decomposition analysis of panel data. World Economic Papers, 2, 96-108 (In Chinese).

Ma, X. (2018a). Economic transition and labor market reform in China. Singapore: Palgrave Macmillan.

Ma, X. (2018b). Ownership sector segmentation and gender wage gap in urban China during the 2000s. Post-Communist Economies, 30(6), 775-804.

Ma, X. (2018c). Labor market segmentation by industry sectors and wage gaps between migrants and local urban residents in urban China. China Economic Review, 47, 96-115.

Meng, X., \& Zhang, J. (2001). Two-tier labor market in urban China: Occupational segregation and wage differentials between urban residents and rural migrants in Shanghai. Journal of Comparative Economics, 29(2), 485-504.

Mincer, J. (1974). Schooling, experience and earning. New York: Columbia University Press.

National Bureau of Statistics (NBS) of China. (2010). China statistical yearbook 2015. Beijing: China Statistics Press (In Chinese).

National Bureau of Statistics (NBS) of China. (2016). China statistical yearbook 2016. Beijing: China Statistics Press (In Chinese).

Song, L., \& Appleton, S. (2006). Urban laid-off workers versus rural migrants: Sectoral choice and job-search. In: F. Cai, \& N. Bai (Eds.), Labor migration in transition China. Beijing: Social Science Academic Press (In Chinese).

Spence, M. A. (1976). Signaling in retrospect and the information structure of markets. American Economic Review, 92(3), 434-459.

Trow, M. (1972). The expansion and transformation of higher education. International Review of Education, 18(1), 61-84.

Trow, M. (1973). Problems in the transition from elite to mass higher education. Carnegie Commission on Higher Education.

Wolf, A. (2002). Does education matter? Myths about education and economic growth. New York: Penguin Books.

Wu, Y., \& Zhao, Q. (2010). Higher education expansion and employment of university graduates. Economic Research Journal, 9, 93-108. (In Chinese).

Xia, Q., Wang, X., Li, S., \& Zhou, H. (2016). The effects of China's higher education expansion on income distribution. Social Science Front, 7, 54-65 (In Chinese).

Xing, C., \& Li, S. (2011). Higher education expansion, education opportunity, and unemployment of college graduates. China Economic Quarterly, 10(4), 1187-1208 (In Chinese). 
Yao, X., Fang, X., \& Qian, X. (2014). The effects of higher education expansion on wage of college graduates. Population \& Economics, 202(1), 67-79 (In Chinese).

Yao, X., Fang, X., \& Zhang, H. (2013). Changes in economic return to schooling and employment rate with the expansion of higher education. Economic Issues in China, 277(2), 3-11. (In Chinese).

Open Access This chapter is licensed under the terms of the Creative Commons AttributionNonCommercial-NoDerivatives 4.0 International License (http://creativecommons.org/licenses/bync-nd/4.0/), which permits any noncommercial use, sharing, distribution and reproduction in any medium or format, as long as you give appropriate credit to the original author(s) and the source, provide a link to the Creative Commons licence and indicate if you modified the licensed material. You do not have permission under this licence to share adapted material derived from this chapter or parts of it.

The images or other third party material in this chapter are included in the chapter's Creative Commons licence, unless indicated otherwise in a credit line to the material. If material is not included in the chapter's Creative Commons licence and your intended use is not permitted by statutory regulation or exceeds the permitted use, you will need to obtain permission directly from the copyright holder.

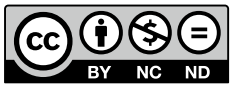

